УДК 621.385 .69

\title{
АВТОМОДУЛЯЦИОННЫЕ И ХАОТИЧЕСКИЕ РЕЖИМЫ ГЕНЕРАЦИИ В ДВУХРЕЗОНАТОРНОМ ГИРОКЛИСТРОНЕ С ЗАПАЗДЫВАЮЩЕЙ ОБРАТНОЙ СВЯЗЬЮ*
}

\author{
Р. М. Розенталь ${ }^{1}$ О. Б. Исаева², Н. С. Гинзбург ${ }^{1}$, \\ И. В. Зотова ${ }^{1}$, А. С. Сергеев ${ }^{1}$, А. Г. Рожнев ${ }^{2}$ В. П. Тараканов ${ }^{3,4}$ \\ 1 Федеральный исследовательский центр Институт прикладной физики РАН \\ Россия, 603950 Н. Новгород, БОКС-120, ул. Ульянова, д. 46 \\ 2 Саратовский филиал Института радиотехники и электроники им. В.А. Котельникова РАН \\ Россия, 410019 Саратов, ул. Зеленая, д. 38 \\ ЗОбъединенный институт высоких температур РАН, Россия, 125412 Москва, ул. Ижорская, \\ д.13 \\ 4НИЯУ «МИФИ», Россия, 115409 Москва, Каширское ш., 31 \\ E-mail: rrz@appl.sci-nnov.ru, isaevao@rambler.ru, ginzburg@appl.sci-nnov.ru, \\ zotova@appl.sci-nnov.ru, sergeev@appl.sci-nnov.ru,rozhnevAG@info.sgu.ru,karat@tarak.msk.su \\ Поступила в редакиию 26.03.2018
}

Тема и цель исследования. Исследована динамика двухрезонаторного гироклистрона диапазона 93 ГГц с запаздывающей обратной связью. Проведен сравнительный анализ динамических режимов, получаемых в численном эксперименте как на основе усредненных уравнений, так и в рамках моделирования методом «крупных частиц» с помощью программного комплекса KARAT. Методы. Для выявления динамических свойств, полученных при моделировании режимов, применен спектр статистических методов теории хаоса: расчет фрактальных размерностей, показателей Ляпунова и др. Для нахождения ляпуновских показателей использован способ оценки их по временным рядам. Этот способ крайне удобен, так как требует лишь одной скалярной временной реализации в фиксированной точке пространственно распределенной системы, например, для амплитуды выходного излучения. Кроме того, способ воспроизводит обработку данных, которые могут быть получены в натурном эксперименте. Результаты. Анализ полученных при численном моделировании временных рядов показал существование гиперхаотических режимов генерации для обоих подходов к моделированию гироклистрона. Таким режимам отвечают аттракторы с высокой корреляционной размерностью и более чем одним положительным ляпуновским показателем. Обнаружено, что указанные гиперхаотические режимы возникают, например, с увеличением коэффициента передачи для цепи обратной связи. Многомодовый «сильный» гиперхаос развивается из хаоса, возникающего в результате последовательности бифуркаций удвоения периода регулярной автомодуляции интенсивности выходного излучения гироклистрона. Обсуждение.Хаотические генераторы и шумотроны СВЧ диапазона крайне ценны для различных технических приложений, например, в радиолокации и широкополосной коммуникации. В связи с этим, получение многомодовых, хаотических и гиперхаотических режимов генерации гироусилителей является приоритетным направлением СВЧ электроники. Предложенные в работе методы моделирования демонстрируют сложные режимы для гироклистрона. Описанные подходы к анализу генераций усилителя могут быть в будущем применены в натурном эксперименте.

Ключевые слова: гироклистрон, запаздывающая обратная связь, развитый хаос.

DOI: 10.18500/0869-6632-2018-26-3-78-98 
Образец цитирования: Розенталь Р.М., Исаева О.Б., Гинзбург Н.С., ЗотоваИ.В., Сергеев А.С., Рожнев А.Г., Тараканов В.П. Автомодуляционные и хаотические режимы генерации в двухрезонаторном гироклистроне с запаздывающей обратной связью // Известия вузов. Прикладная нелинейная динамика. 2018. Т. 26, № 3. С. 78-98. DOI: 10.18500/08696632-2018-26-3-78-98

\title{
AUTOMODULATION AND CHAOTIC REGIMES OF GENERATION IN A TWO-RESONATOR GYROKLYSTRON WITH DELAYED FEEDBACK
}

\author{
R. M. Rozental ${ }^{1}$, O. B. Isaeva ${ }^{2}$, N. S. Ginzburg ${ }^{1}$, I. V. Zotova ${ }^{1}$, \\ A. S. Sergeev ${ }^{l}$, A. G. Rozhnev ${ }^{2}$, V. P. Tarakanov ${ }^{3,4}$ \\ ${ }^{1}$ Federal Research Center The Institute of Applied Physics of RAS \\ 46, Ul'yanova str., Box-120, 603950 N. Novgorod, Russia \\ ${ }^{2}$ Kotelnikov Institute of Radio-Engineering and Electronics of RAS, \\ Saratov Branch 38, Zelenaya str., 410019 Saratov, Russia \\ ${ }^{3}$ Joint Institute for High Temperatures of RAS \\ 13, Izhorskaya str., build 2, 125412 Moscow, Russia \\ ${ }^{4}$ National Research Nuclear University «MEPhI» \\ 31, Kashirskoye avenue, 115409 Moscow, Russia \\ E-mail: rrz@appl.sci-nnov.ru, isaevao@rambler.ru, ginzburg@appl.sci-nnov.ru, \\ zotova@appl.sci-nnov.ru, sergeev@appl.sci-nnov.ru,rozhnevAG@info.sgu.ru,karat@tarak.msk.su \\ Received 26.03.2018
}

Topic and aim. The dynamics of a double-resonator gyroklystron of the $93 \mathrm{GHz}$ band with delayed feedback is studied. A comparative analysis of the dynamical regimes of amplifier generation obtained in the numerical experiment both on the basis of averaged equations and in the framework of direct numerical simulation by the «particle-in-cells» method using the KARAT code is carried out.

Method. To identify the dynamical properties of system behavior we apply the spectrum of of statistical methods from the theory of chaos: the calculation of fractal dimensions, Lyapunov exponents, etc. To find the Lyapunov exponents we apply a method of estimating them from dynamical time series. This method is extremely convenient, since it requires only the single scalar time realization in a fixed in space point of spatially distributed system, for example, the amplitude of output radiation. Moreover, this method imitates the processing of the data that can be obtained in natural experiment. Results. The analysis of the time series obtained in numerical simulation showed the existence of hyperchaotic regimes for both approaches to the modeling of gyroklystron. Such regimes correspond to attractors with a high correlation dimension and more than one positive Lyapunov exponents. It was found that mentioned hyperchaotic regimes occur, for example, with an increase in the transmission factor for the feedback loop. The multimode «strong» hyper-chaos arises from chaos resulting from the sequence of period doubling bifurcations of the periodic automodulation mode intensity of output radiation gyroklystron. Discussion. UHF chaotic and noise generators are extremely important for various technical applications. One can note, for example, radars and wideband communication. Thus, the production of multimode, chaotic and hyper-chaotic regimes of gyro-amplifiers generation is a priority branch of microwave electronics. Being proposed in this paper the mathematical modeling methods allow to detect complex regimes for gyroklystron. 
Being proposed in this paper the approaches to amplifier generations analysis can be applied in a physical experiment.

Keywords: gyroklystron, delayed feedback, strong chaos.

DOI: 10.18500/0869-6632-2018-26-3-78-98

References: Automodulation and chaotic regimes of generation in a two-resonator gyroklystron with delayed feedback. Izvestiya VUZ, Applied Nonlinear Dynamics, 2018, vol. 26, no. 3, pp. 78-98. DOI: 10.18500/0869-6632-2018-26-3-78-98

*Статья написана по материалам доклада на XVII международной зимней школе-семинаре по радиофизике и электронике СВЧ. Россия, Саратов, 5-10.02.2018 